\title{
Evaluation of analgesic and anti-inflammatory activities of Warionia saharae essential oil
}

\author{
Mimouna Yakoubi ${ }^{\mathrm{a}, \mathrm{b} *}$, Nasser Belboukhari ${ }^{\mathrm{a}}$, Khaled Sekkoumª ${ }^{\mathrm{a}}$, Mohammed Bouchekara ${ }^{\mathrm{b}}$, \\ Hassan Y. Aboul-Enein ${ }^{c}$ \\ ${ }^{a}$ Bioactive Molecules and Chiral Separation Laboratory, PO Box 417, University of Bechar, Bechar 08000, Algeria \\ ${ }^{b}$ Process Engineering and Solution Chemistry Laboratory, University Mustapha Stambouli of Mascara, PO Box 305, Mascara 29000, \\ Algeria \\ ‘Pharmaceutical and Medicinal Chemistry Department, Pharmaceutical and Drug Industries Research Division, National Research Center, \\ Dokeki, Giza 12622, Egypt
}

Received 10th January 2021 / Accepted 14th August 2021

\begin{abstract}
Warionia sabarae Benth \& Coss (W.s) (Asteraceae) is a monospecific genus endemic to Algeria and Morocco. Its leaves are used in their traditional medicine, such as gastrointestinal and inflammatory diseases; for instance, rheumatoid arthritis treatment. In this work, our team investigated the antiinflammatory and analgesic effects of essential oil extracted from the dried upper parts of $W$ arionia saharae based on different standard experimental test models. The analgesic activity was assessed by central and peripheral models, such as "hot plate" and "writhing" tests on Swiss albino mice. The hot plate test used latency measurements to assess acute cutaneous pain sensitivity, as a result; the latency of the hind-paw pain response was by licking and either shaking or jumping, those occurrences were recorded. Writhing test as a chemical method used to induce pain of peripheral origin in mice by injecting acetic acid intraperitoneally (IP). This results in characteristic stretching behavior of the animals (cramps and contortions). The evaluation of the analgesic activity, shows that the essential oil of this plant induces a decrease in the number of abdominal cramps in the contortion test and a maximum inhibition of pain. As for the anti-inflammatory effect, it was studied by the "paw edema" test, a phlogogenic agent (formaldehyde) was used to stimulate inflammation in the paws of mice. Anti-inflammatory properties can be observed by inhibiting this edema compared to the standard drug Diclofenac. In conclusion, Warionia sabarae essential oil $(75 \mathrm{mg} / \mathrm{kg})$ showed a strong anti-inflammatory and analgesic activities which supports the conventional use of this plant in traditional medicine.
\end{abstract}

Keywords: analgesic effects, anti-inflammatory effects, essential oils, medicinal plants, Swiss Albinos mice, Warionia sabarae.

\section{INTRODUCTION}

Painful sensation manifests in different forms (burning, stinging, cramp, gravity, stretching, etc.) of varying intensity and extension (Larousse Médical, 2006). Inflammation is localized reaction of a tissue, resulting from an aggression (Larousse Médical, 2006; Panda et al., 2009). It manifests itself in four main signs: redness, heat, tumefaction (swelling) and pain. When tissue undergoes aggression, the specialized cells, the mast cells, release bradykinin, prostaglandins, histamine, serotonin and adenosine triphosphate), which stimulate vasodilatation in the affected part causing redness and heat. The overloaded capillaries release fluid which seeps into the

\footnotetext{
*Author for correspondence: Mimouna Yakoubi, Bioactive Molecules and Chiral Separation Laboratory, Fac Exact Sciences, University Tahri Mohamed, Bechar 08000,Algeria. Email-amounyak@yahoo.fr
} 
tissues causing swelling and painful sensation. This sensation is caused by stimulation of local nerve endings (Beaulieu, 2005; Larousse Médical, 2006; Ohishia et al., 2016). The inflammatory mechanism was used to eliminate the pathogen and restore damage to the tissue (Ohishia et al., 2016; Sherwood \& Toliver-Kinsky, 2004).

Many plants and herbs such as ginger (Zingiber officinale "Zingibéracées"), curcuma (Curcuma aromatica syn. C. domestica "Zingibéracées") and liquorice (Glycyrrbiza glabra "Fabacées") have shown to exhibit potent anti-inflammatory effects (Larousse Médical, 2001). Warionia saharae (W.s) has also been used in traditional medicine, as an anti-inflammatory and in the treatment of gastrointestinal, jaundice (Amezouar et al., 2012; Bellkhadar, 1997; Hilmi et al., 2003), and in some areas, this plant was used against brucellosis (Yakoubi et al., 2015). Dried leaf decoctions were used against arthritis and epilepsy (Bellakhdar et al., 1986; Katinas et al., 2008). In this context, our laboratory began to inspect the anti-inflammatory and analgesic activities of this species after performing a bibliographic search and an ethnopharmaceutical investigation survey carried out by our team in the region (Yakoubi et al., 2015).

\section{MATERIALS AND METHODS}

\section{Animal materials}

Permission was obtained from the Committee of use of animal experiments (Approval \# 1943-19). Swiss Albino mice weighing 23-43 g of either sex were obtained from Pasteur animal house (Algiers). Animals accommodated under normal laboratory conditions, were kept under a 12/12 hours of dark / light cycle at $25 \pm 1{ }^{\circ} \mathrm{C}$ (Lalitha et al., 2010; Panda et al., 2009) and supplemented with mouse feeding; with free access to water.

Before the experiment, the mice were fasted for $16 \mathrm{~h}$ with free access to water (Riahi et al., 2011; Sanogo et al., 2006). We used prizes of 6 mice range for each experience. It is important to reduce fear, discomfort, pain or distress caused by experimental procedures as long as animal use continues. (Zimmermann, 1983).

\section{Plant materials}

Aerial parts of W.s were collected from Bechar region and voucher specimens were deposited at herbarium of chemistry laboratory, Bechar University. We relied on A.N.N (National Agency Nature protection- Bechar, Algéria) to identify and classify plant.

The air-dried aerial parts of W.s were subjected to hydro-distillation. Once obtained, the extracted essential oil (E.O) was stored in airtight containers before further analysis.

\section{Acute toxicity studies}

The animals were divided into 3 groups of 6 animals each. The extract was administered at doses of 50, 75, 100 and $200 \mathrm{mg} / \mathrm{kg}$ of animal body weight; transmitted by intraperitoneal (IP) injection. The observation period of the symptoms of intoxication and lethality lasted for 48 hours (Lalitha et al., 210; Soro et al., 2015).

\section{Analgesic activity}

The "writhing" and "hot plate" tests were the most used; they were classified among the five most common nociception tests (Bars et al., 2001).

\section{Acetic acid-induced writhing in mice}

To assess analgesic activity and preferentially assess the potential oceanic effects of essential oils as analgesic substances, we used writhing method (Silva, 2003).

All the treatments were administrated by IP injection. Approximately $30 \mathrm{~min}$ after each administration; the writhing was provoked by the IP injection of acetic acid $(0.6 \%, 10 \mathrm{ml} / \mathrm{kg})$ (Makambila-Koubemba et al., 1997; Sieg-mund et al., 1957). We waited $5 \mathrm{~min}$ before the observation, then counted the number of convulsions the mouse exerted for a period of 30 minutes.

Mice were grouped into 4 groups of 6 animals each: Group 1 received physiological water which served as control group. Groups 2 and 3 received ASPEGIC $^{\circledR}$ at dose 250 and $500 \mathrm{mg} / \mathrm{kg}$ respectively; served as the standard group. Acetylsalicylic acid (ASPEGIC ${ }^{\circledR}$ ) is a well-known peripheral analgesic drug (Sieg-mund et al., 1957; Silva et al., 2003) and it was used as a positive control in the present investigation. Group 4 received essential oil of W.s $(75 \mathrm{mg} / \mathrm{kg})$. 
The calculation formula is as follows (Diatta et al., 2014; Riahi et al., 2011):

$$
\text { Inhibition }(\%)=\left(\frac{\mathrm{Mc}-\mathrm{Mt}}{\mathrm{Mc}}\right) \cdot 100
$$

Inhibition (\%): Percentage inhibition of pain Mc: Number of writhing in control

Mt: Number of writhing in test (treatment)

\section{Hot plate test}

Hot plate test assesses the central analgesic effects of an essential oil (MacDonald et al., 1946; Silva et al., 2003).

The latency period of response to a thermal stimulus applied to the paw, is determined by the time it takes the mouse to lick its paw, or jump from the hot plate surface; these reflexive behaviors involve both cerebral and spinal mediated circuit (Ankier et al., 1974; Bars et al., 1992; Mulder et al., 2004).

The method as described by Turner et al. (1965), every mouse (23-43 g) was placed softly on a hot plate maintained at $55^{\circ} \mathrm{C} \pm 1$, the appropriate temperature for this test (Menèndez et al., 2002; Tjolsen et al., 1991); 15 min before (Silva et al., 2003), without exposing the animals to tissue damage (Eddy et al., 1953; Tjolsen et al., 1991). The surface of the hotplate is cleaned with $70 \%$ ethanol between the testing of each mouse (IACUC). Each experimental group was performed with at least six animals: Group 1 received physiological water which served as control group. Group 2 received ASPEGIC ${ }^{\circledR}(500$ $\mathrm{mg} / \mathrm{kg}$ ), served as the standard group. Group 3 received essential oil extracted from W.s (75 $\mathrm{mg} / \mathrm{kg}$ ). All treatments were given by IP injection. At $0,15,30$, and 45 min post-treatment, we recorded each reaction time of the controlled and treated animals (MacDonald et al., 1946; Silva et al., 2003). The percentage of inhibition was obtained by:

$$
\text { Inhibition }(\%)=\left(\frac{\mathrm{MRTa}-\mathrm{MRTb}}{\mathrm{MRTb}}\right) \cdot 100
$$

Inhibition (\%): Percentage inhibition of thermal pain

MRTa: Means reaction time after administration

MRTb: Means reaction time before administration

\section{Anti-inflammatory activity Inflammatory paw edema}

Induction of acute inflammation in all groups was obtained by the injection of a phlogogenic agent such as $1 \%$ formalin solution $(0.025 \mathrm{ml} / \mathrm{kg})$, under the plantar aponeurosis of the hind paw of the mice. This solution induces an inflammatory reaction, which can be reduced by antiinflammatory substances (Sen et al., 1991; Winter et al., 1962). The evolution of the inflammatory response and the measurement of the edema volumes are monitored by the plethysmometer (Model LE 7500, Bioseb, Barcelona, Spain) (Riahi et al., 2011).

Paw volume was measured $30 \mathrm{~min}$ prior to formalin injection; and at 0, 30, 60, 120, and 180 min after the injection (Panda et al., 2009).

The albino mice were divided into 3 groups of 6 animals each; all of treatments were administered by IP injection, $30 \mathrm{~min}$ before the injection formaldehyde 1\%: Group 1 received physiological water which served as control group. Group 2 received Diclofenac $(25 \mathrm{mg} / \mathrm{kg}$, $10 \mu \mathrm{l} / \mathrm{g}$ ), served as the standard group. Group 3 received essential oil of W.s ( $75 \mathrm{mg} / \mathrm{kg})$.

The volume of edema at a given time was recorded and translated into percent inhibition. The anti-inflammatory activity was evaluated by calculating the mean percentages of inhibition of edema using the formula (Ndiaye et al., 2006; Panda et al., 2009):

$$
\text { Inhibition }(\%)=\left(\frac{\mathrm{V} c-\mathrm{Vt}}{\mathrm{Vc}}\right) \cdot 100
$$

Inhibition (\%): Percentage inhibition of edema Vc: Edema volume in control

$\mathrm{Vt}$ : Edema volume in test (treatment)

\section{Statistical analysis}

Statistical analysis was performed, using GraphPad Prism 7 (Student's t-test) software. All values were expressed as Mean \pm SEM. Values of $\mathrm{p} \leq 0.05$ were considered significant. 


\section{RESULTS}

\section{Acute toxicity studies}

The essential oil of W.s administered to the mice at doses ranging from 50 to $200 \mathrm{mg} / \mathrm{kg}$ by the intraperitoneal (IP) route carried no mortality during ( $2 \mathrm{~h}, 24 \mathrm{~h}$, and $48 \mathrm{~h}$ ) (Table 1). However, the dose of $200 \mathrm{mg} / \mathrm{kg}$ presented signs of toxicity (hypoactivity, drowsiness and tachycardia).

We then chose $75 \mathrm{mg} / \mathrm{kg}$ as the working dose for the subsequent tests as there were no physiological changes observed at $48 \mathrm{~h}$ posttreatment.

Table 1. Results of acute toxicity test (short term result $48 \mathrm{~h}$ ).

\begin{tabular}{cccccc}
\hline Injected & Doses & \multicolumn{3}{c}{ Symptoms } & \multirow{2}{*}{ Mortality } \\
\cline { 3 - 5 } product & $\mathbf{m g} / \mathbf{k g})$ & Hypoactivity & Drowsiness & Tachycardia & \\
\hline & 50 & - & - & - & 0 \\
Essential oil W.s & 75 & - & - & - & 0 \\
& 100 & + & + & + & 0 \\
& 200 & ++ & ++ & ++ & 0 \\
\hline
\end{tabular}

-: No signs

+ : Low signs

\section{Analgesic activity}

\section{Acetic acid-induced writhing in mice}

We have performed screening of analgesic activity of essential oil. This activity was demonstrated by the abdominal cramp test.

In the group of mice treated with ASPEGIC ${ }^{\circledR}$ at dose $500 \mathrm{mg} / \mathrm{kg}$, the analgesic activity showed significant effect when compared with ASPEGIC $^{\circledR}$ at dose of $250 \mathrm{mg} / \mathrm{kg}$ as well as standard drug (Figure 1).

Regarding our extract it was very effective against pain in which it completely suppressed writhing, which means a perfect elimination of nociception (Figure 1).

After injection of acetic acid into the control group of mice, $75 \pm 2$ abdominal cramps are recorded for $30 \mathrm{~min}$. In the presence of ASPEGIC ${ }^{\circledR}$ at $250,500 \mathrm{mg} / \mathrm{kg}$ and essential oil of Ws at $75 \mathrm{mg} \mathrm{kg}$, the number of abdominal cramps decreases in the same time interval. It passes respectively to; $60 \pm 3,26 \pm 5$, and 0 cramps.

Moreover, the W.s essential oil totally suppressed pain in mice with a percentage of inhibition of $100 \%$, except some symptoms such as licking of the hind paw. While the percentage of inhibition of ASPEGIC ${ }^{\circledR}$ was $63.51 \%$ for dose $500 \mathrm{mg} / \mathrm{kg}, 250 \mathrm{mg} / \mathrm{kg}$ of ASPEGIC ${ }^{\circledR}$ only resulted in 20.94\% inhibition (Figure 2), which is originally, classified as peripheral analgesics. This implies that essential oil possesses a strong peripheral analgesic activity, or probably contains one or more molecules belonging to the class of peripheral analgesics which can certainly be compared to the effect of morphine against pain caused by acetic acid, with maximum inhibition of $98.37 \%$ (Ramirez et al., 2010) at 100\% according to the results of Makambila-Koubemba et al., (1997).

\section{Hot plate test}

After evaluating the hot plate test, we found that when administering the essential oil, the reaction time was prolonged at several times after $30 \mathrm{~min}$ of treatment.

The reaction time in control and treated animals was recorded at 15, 30, 45, and $60 \mathrm{~min}$ after the treatment; the jump out was made after 5 to $7 \pm 0.02 \mathrm{~min}$ ( after each deposit) for the mice that have received the essential oil of W.s (Figure 3); also to $6 \pm 0.01 \mathrm{~min}$ for the mice that have received ASPEGIC ${ }^{\circledR}$ drug, whilst in the control group; reacted very quickly they took 3.0 to $4 \pm 0.05 \mathrm{~min}$ to jump out of retention cylinder.

Our results confirmed that the essential oil of W.s significantly increased the reaction time about $75 \%$, greater than ASPEGIC ${ }^{\circledR}$ drug which reached $42 \%$ of inhibition (Figure 4). Therefore, our essential oil showed an important central analgesic activity. 


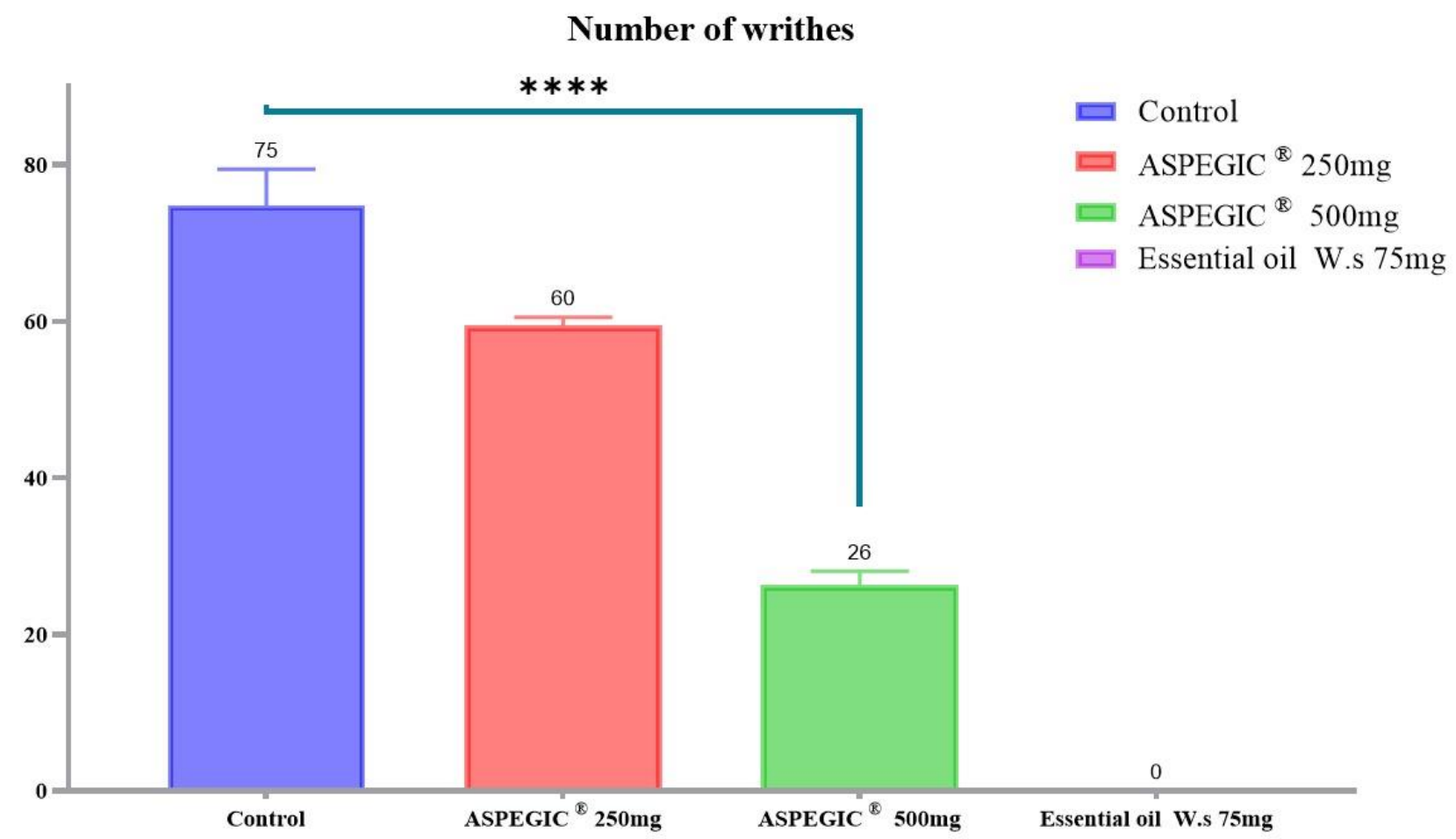

Figure 1. Analgesic activity of W.s-E.O by writhing test. $\mathrm{n}=6$. Values are expressed as mean \pm SEM. **** $\mathrm{P}<0.0001$, when compared with control group.

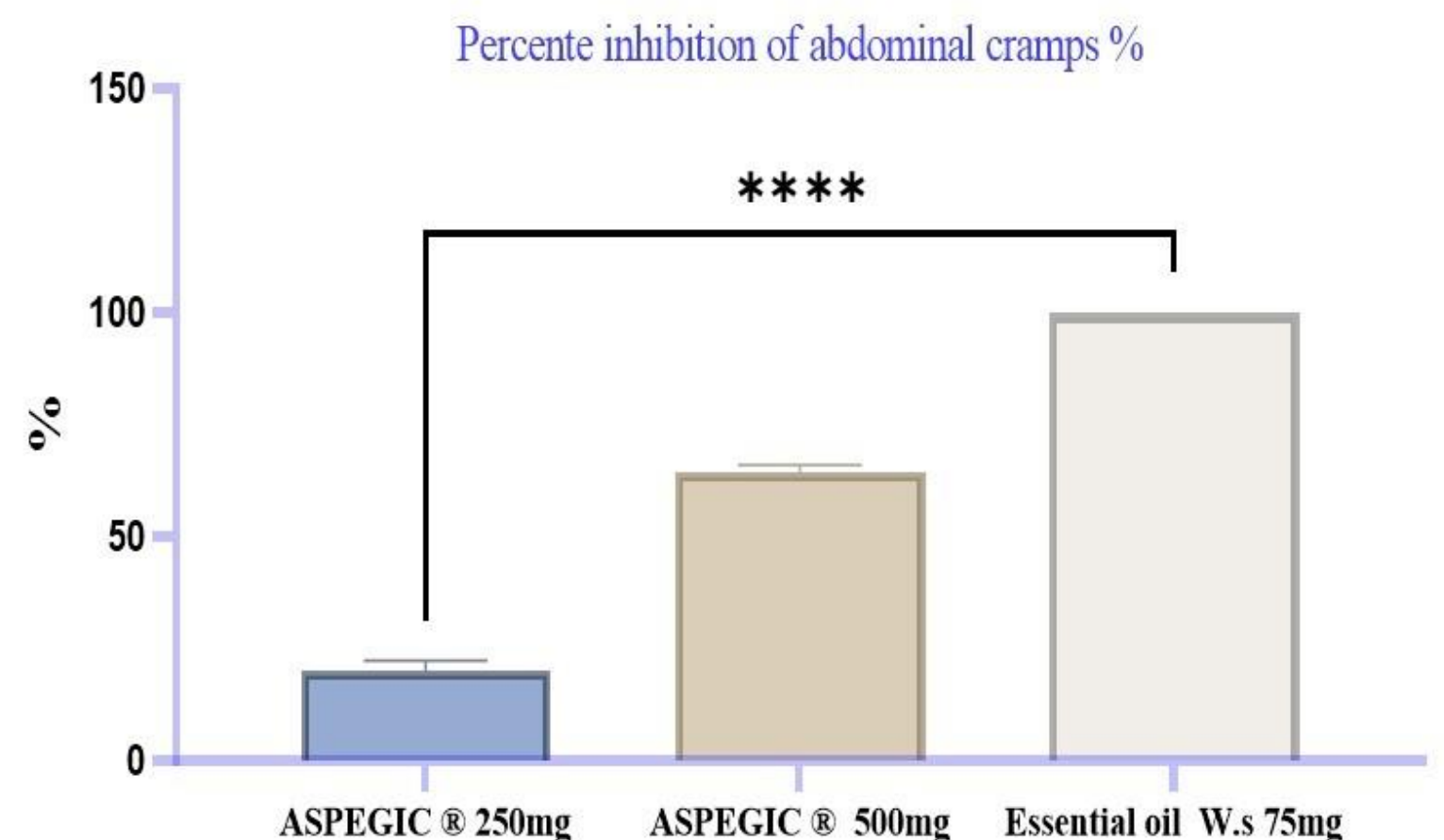

Figure 2. Percentage of inhibition of abdominal cramps induced by acetic acid. $n=6$. Data are expressed as mean \pm SEM. ${ }^{* * * *}$ P value $<0.0001$ as compared to the E.O group. 


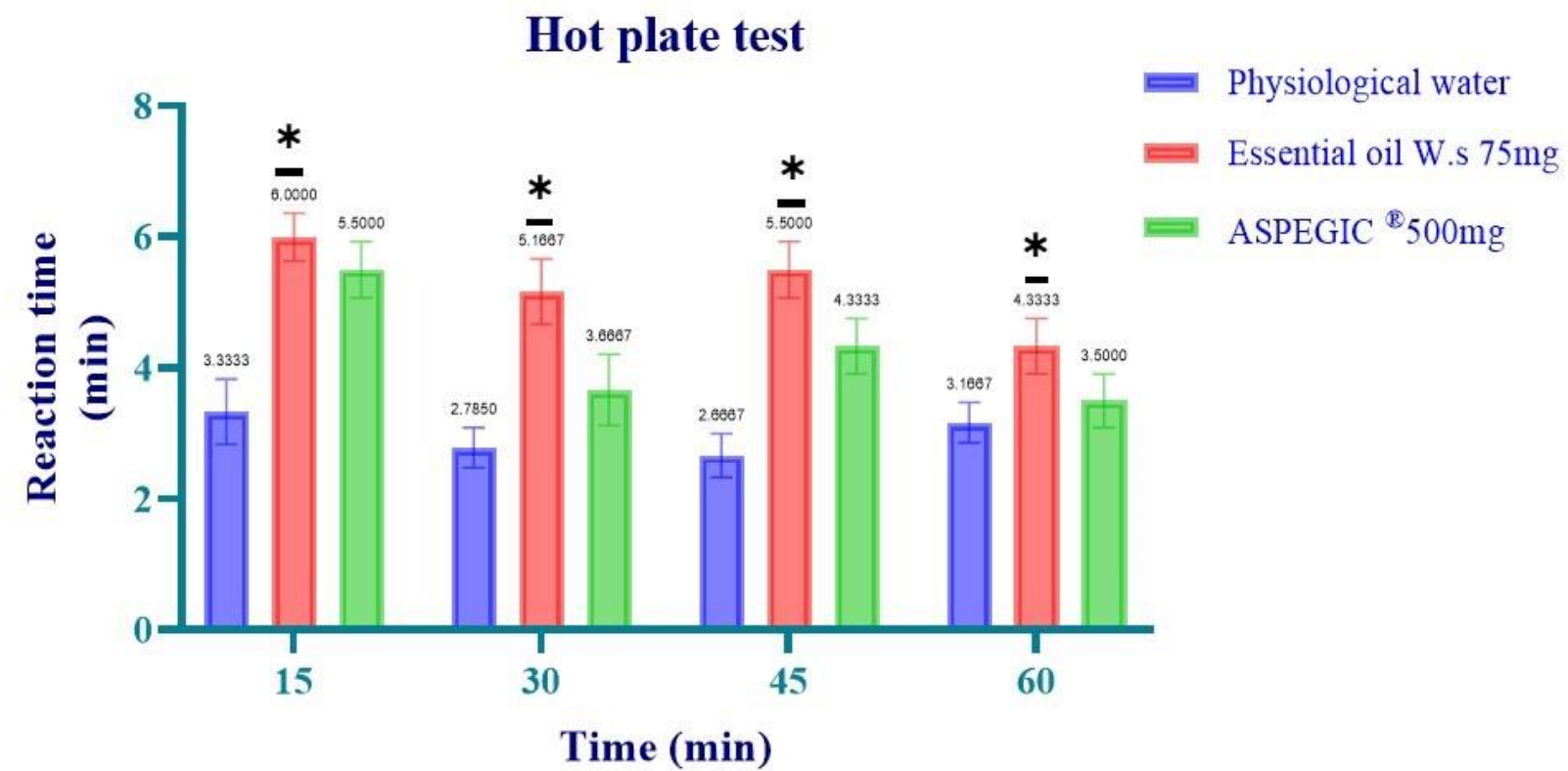

Figure 3. Analgesic activity of W.s-E.O, by hot plate method. $n=6$. Significant different among means $* \mathrm{P}<0.05$ when compared with control group.

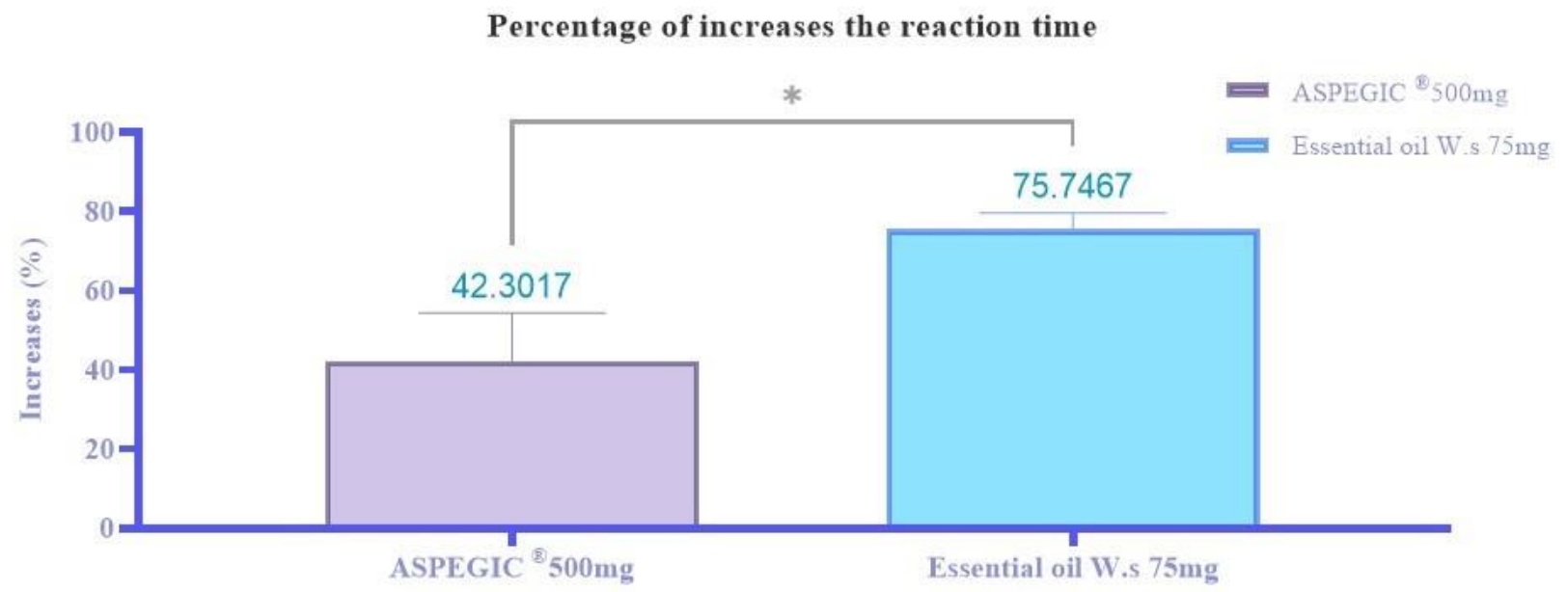

Figure 4. Percentage of increases the reaction time (hot plate test). Data are expressed as mean \pm SEM. Significantly different $\left({ }^{*} \mathrm{P}<0.05\right) . \mathrm{n}=6$.

\section{Anti-inflammatory activity Inflammatory paw edema}

The evaluation of anti-inflammatory efficacy is based on the paw edema process caused by the IP injection of formaldehyde. The graph of figure 5 showed that the animals treated with E.O demonstrated a significant decrease in the edema volume, better than the group treated with Diclofenac especially after $60 \mathrm{~min}$ of treatment
(Figure 5). Inhibition is also remarkable compared to the negative control. We obtained a reduction of paw volume by $68 \%$ after 3 hours for mice that received E.O treatment (Figure 6). Meanwhile, the standard drug only reduced the paw edema by $48 \%$. Thus, W.s essential oil has a stronger antiinflammatory activity as compared to the standard drug; Diclofenac treated animals. Percentage of inhibition of edema is presented in Figure 6. 


\section{Increase in paw volume}

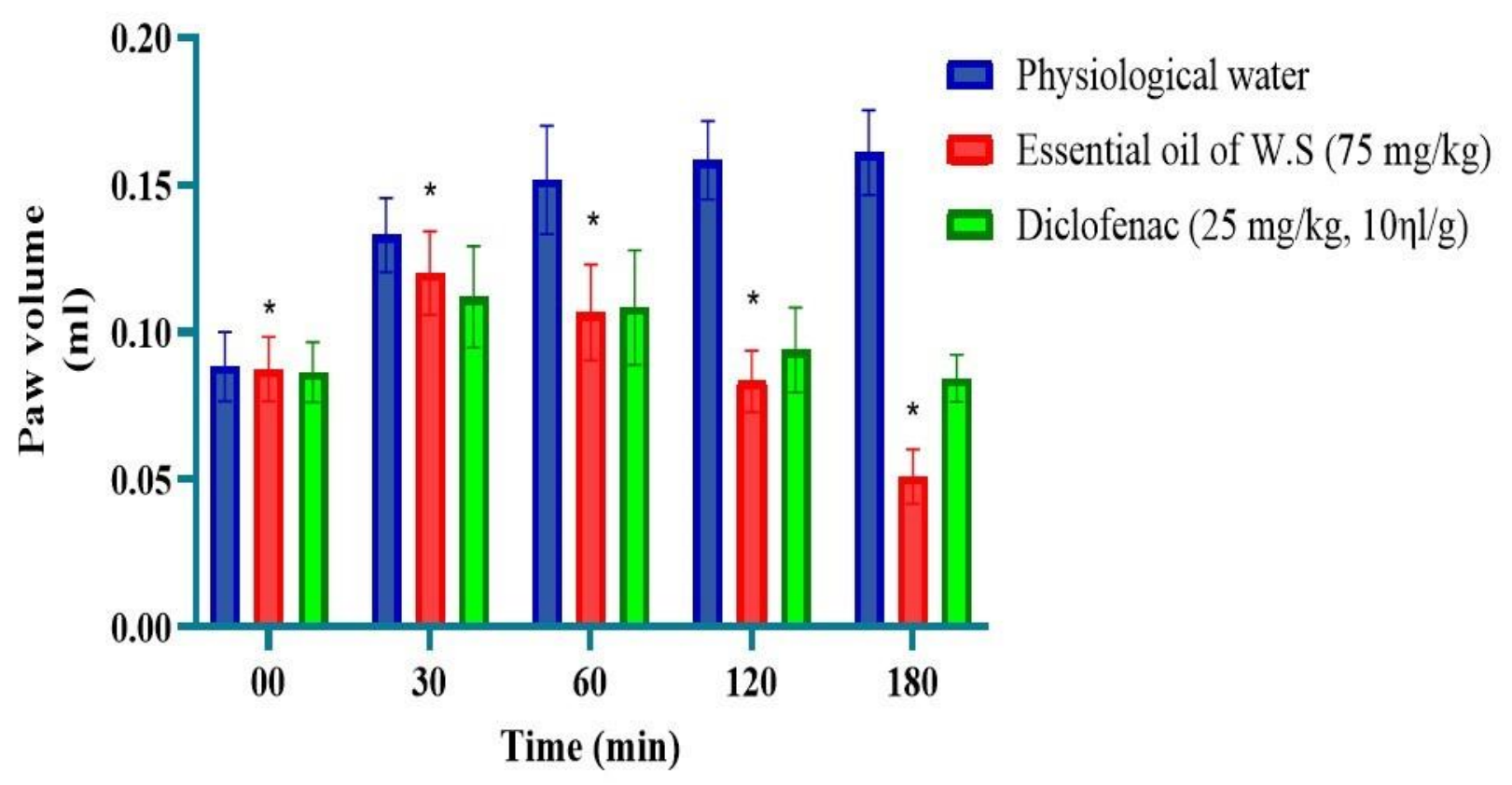

Figure 5. Anti-inflammatory activity of W.s-E.O by paw edema method. Asterisk $\left(^{*}\right)$ indicates a significant difference between treatments $(\mathrm{p}<0.05), \mathrm{n}=6$.

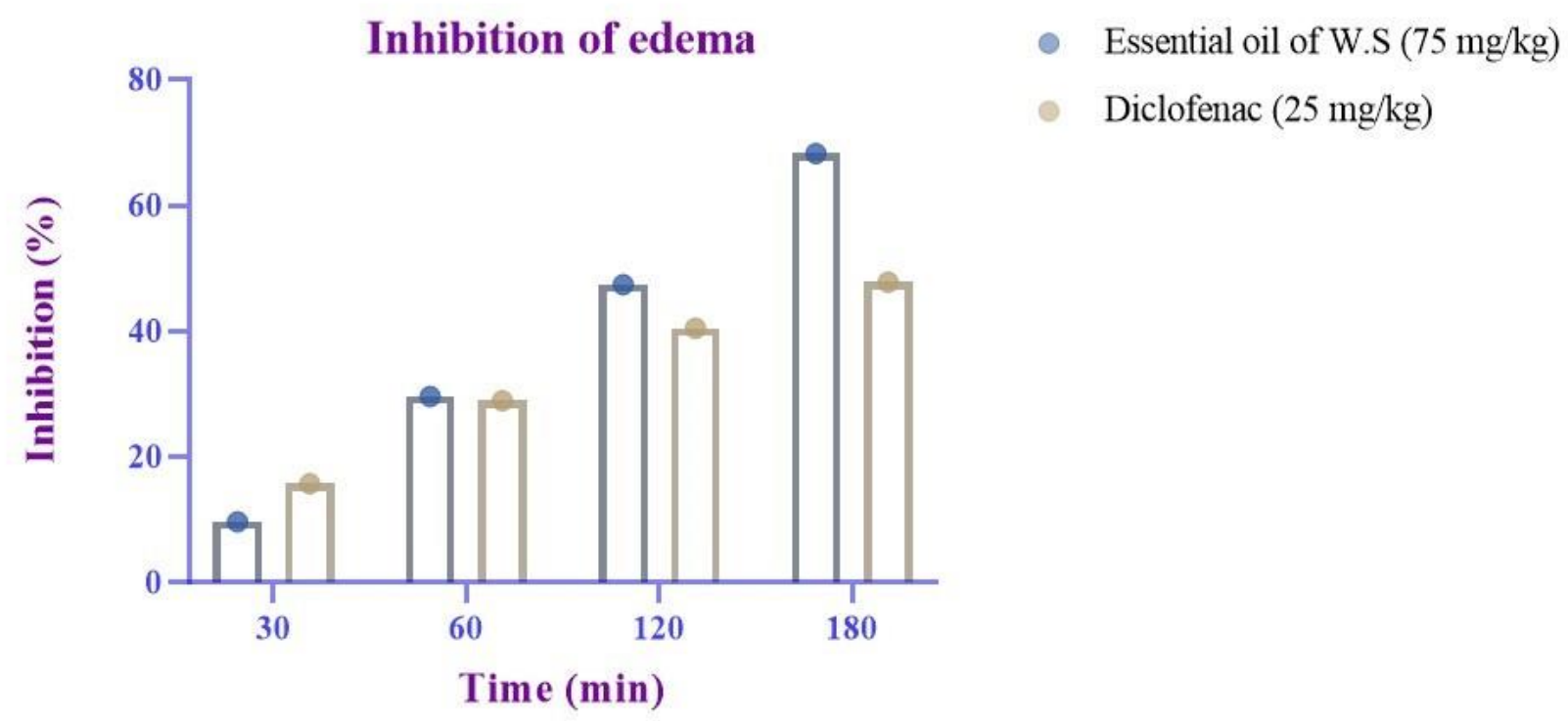

Figure 6. Percentage of inhibition of paw volume. $n=6$. Data are expressed as mean \pm SEM. Significant difference between treatments $(\mathrm{p}<0.05)$.

\section{DISCUSSION}

This study provides an evidence that the essential oil of Warionia sabarae possesses excellent analgesic and anti-inflammatory effects. These activities can be due to the terpenes and sesquiterpenes present in the essential oil (Franchomme et al., 2001; Kaloustian et al., 2012) particularly monoterpenes which have secretolytic properties against several inflammatory mediators (Juergens et al., 1998b). Our essential oil may also 
contain terpenols and sesquiterpenols (Yakoubi et al., 2015), which have been shown to have antiinflammatory and analgesic effects (Franchomme et al., 2001; Kaloustian et al., 2012). Also, the terpenic and no-terpenic esters show a powerful anti-inflammatory activity (actives on primary phase of inflammation) (Franchomme et al., 2001).

Inhibition of the synthesis of prostaglandin (PG) and reduction in the release of chemical mediators that activate, sensitize, or awaken pain nociceptors has been generally recognized as the mechanism behind the pharmacological actions of both the therapeutic and adverse effects of medications since the 1970s (Chan et al., 2016; Hamza et al., 2009).

Both acetic acid and hot plate tests cause tissue damage and, in turn, release a number of chemical mediators such as bradykinin, histamine, serotonin, acetylcholine, and prostaglandins. This results in pain by sensitizing a nociceptor (Beaulieu et al., 2005; Collier et al., 1968; Le Bars et al., 2001; Raj et al., 1996). The results reveal that the essential oil of W.s has an antinociceptive effect (analgesic effect).

Our research focused on the antiinflammatory effect of W.s essential oil, whichever was based on formalin-induced mouse paw edema. This inflammatory response comprises three distinct phases: a first phase involving histamine and 5-hydroxytryptamine, which promote vasodilation, plasma transudation and edema; a second phase that uses kinins as mediators increases vascular permeability and a third phase whose mediator is supposed to be prostaglandin (Attal et al., 2000; Essaqui et al., 2007; Lindsey et al., 1999; Raj et al., 1996; Sanogo et al., 2006). A positive effect could be explained by the inhibition of the actions or synthesis of pro-inflammatory substances. The findings also show that W.s essential oils greatly inhibited histamine-induced vascular permeability.

The main component of the Warionia saharae essential oil, $\beta$-eudesmol (Essaqui et al., 2007, Sellam et al., 2012; Yakoubi et al., 2015; Znini et al., 2013), has several pharmacological activities, among them an anti-inflammatory activity. A thorough study has explained the mechanism of $\beta$-eudesmol against inflammations (Kim et al., 2018; Seo et al., 2011). $\beta$-eudesmol inhibited the production and expression of interleukin-6 (IL-6) and p38 MAPK and nuclear factor NF-xB. In addition, it also suppressed receptor-interacting protein 2 (RIP2) and caspase-1 activation induced by phorbol 12-myristate 13-acetate calcium ionophore A23187

(PMACI) (Koonrungsesomboon et al., 2014; Seo et al., 2011). Another study has proved that in high concentrations of $\beta$-eudesmol could block neuromuscular transmission (Kimura et al., 1991; Chiou et al., 1992).

\section{CONCLUSION}

Our data showed that W.s essential oil have both central and peripheral analgesic effects, as well as anti-inflammatory effects. With a highest peripheral anti-nociceptive activity., Hence, these results support the traditional use of the plant against inflammation. However, additional research is required to clarify the molecular and cellular dynamics of these effects and determination of the active compounds in the essential oil of Warionia sabarae.

\section{CONFLICT OF INTERESTS}

All authors have completed the ICMJE uniform disclosure form and declare no support from any organization for the submitted work.

\section{REFERENCES}

Attal, N. \& Bouhassira, D. 2000. Nouvelles approches pharmacologiques de la douleur. Annales Pharmacentiques Française 58: 121-134.

Amezouar, F., Badri, W., Hsaine, M., Aksim, M., Bourhim, N., \& Fougrach, H. 2012. Subacute toxicity, anti-inflammatory and antioxidant activities of ethanolic extract of Moroccan Warionia saharae from Tata region. International Journal of Pharmacy and Pharmaceutical Science 4 (5): 528-533.

Ankier, S. I. 1974 New hot plate tests to quantify antinociceptive and narcotic antagonist activities. European Journal of Pharmacology 27: 1-4.

Bars, D. L., Gozariu, M., \& Cadden, S. W. 2001. Évaluation de la douleur aiguë chez l'animal d'expérience. Première partie. Annales Françaises d'Anesthésie et de Réanimation 20: 347-65.

Chiou, L. C. \& Chang, C. C. 1992. Antagonism by $\beta$-eudesmol of neostigmine-induced neuromuscular failure in mouse diaphragms. European Journal of Pharmacology 216(2): 199-206.

Beaulieu, P. 2005. Pharmacologie de la douleur. PUM Éd, Canada. 
Chapitre 1-S. Marchand.

Bellakhdar, J., Baayaoui, A., Kazdari, A., \& Marechal, J. 1986. Herboristes et medecine traditionnelle à Tissint, oasis presaharien du sud Marocain (Province de Tata). Al Biruniya 3: 7-50.

Bellkhadar, J. 1997. La pharmacopée marocaine traditionelle; medicine arabe ancienne et savoir populaires. IBIS Press, pp. 213.

Chan, W. K., Tan, L. T. H., Chan, K. G., Lee, L. H., \& Goh, B. H. 2016. Nerolidol: A sesquiterpene alcohol with multi-faceted pharmacological and biological activities. Molecules 21: 529.

Collier, H. O. J., Dinneen, L. C., Johnson, C. A., \& Schneider, C. 1968. The abdominal response and its suppression by analgesic drugs in the mouse. British Journal of Pharmacology and Chemotherapy 32: 295-310.

Diatta, W., Yoro, S. Y. G., Manga, C. I., Diatta, K., Fall, A. D., \& Bassene, E. 2014. Recherche des activités antiinflammatoire et analgésique des extraits de feuilles de Zanthoxylum zanthoxyloides (Lam) zepernick et timler (Rutaceae). International Journal of Biological Chemistry 8(1): 128133.

Eddy, N. B. \& Leimbach, D. 1953. Synthetic analgesics: II. Dithienylbutenyl- and dithienylbutylamines. Journal of Pharmacology and Experimental Therapeutics 107: 385-393.

Essaqui, A., Elamrani, A., Cayuela, J. A., \& Benaissa, M. 2007. Chemical composition of the essential oil of Warionia sabarae from Morocco. Journal of Essential Oil-Bear Plants 10(3): 241-246.

Franchomme, P., Jollois, R., \& Pénoël, D. 2001. L'aromathérapie exactement: Encyclopédie de l'utilisation thérapeutique des huiles essentielles, fondements, démonstration, illustration et applications d'une science médicale naturelle. Roger Jolloi Editions, pp. 510.

Hamza, M. \& Raymond, A. D. 2009. Mechanisms of non-opioid analgesics beyond cyclooxygenase enzyme inhibition. Current Molecular Pharmacology 2(1): 1-14.

Hilmi, F., Sticher, O., \& Heilmann, J. 2003. New cytotoxic sesquiterpene lactones from $W$ arionia sabarae. Planta Medica 69: 462-464.

Juergens, U. R., Stober, M., Schmidt-Schilling, L., Kleuver, T., \& Vetter, H. 1998b. Antiinflammatory effects of eucalyptol (1,8-cineole) in bronchial asthma: Inhibition of arachidonic acid metabolism in human blood monocytes ex vivo. European Journal of Medical Research 3: 407-412.

Kaloustian, J. \& Hadji-Minaglou, F. 2012. La connaissance des huiles essentielles : qualitologie et aromathérapie, Entre science et tradition pour une application médicale raisonnée. Springer-Verlag France, Paris pp. 176-218.

Katinas, L., Tellería, M. C., Susanna, A., \& Ortiz, S. 2008. Warionia (Asteraceae): a relict genus of Cichorieae? Anales del Jardin Botánico de Madrid 65(2): 367-381.

Kim, K. Y. 2018. Anti-inflammatory and ECM gene expression modulations of $\beta$-eudesmol via NF- $x \mathrm{~B}$ signaling pathway in normal human dermal fibroblasts. Biomedical Dermatology 2(1):3.

Kimura, M., Nojima, H., Muroi, M., \& Kimura, I. 1991. Mechanism of the blocking action of $\beta$-eudesmol on the nicotinic acetylcholine receptor channel in mouse skeletal muscles. Neuropharmacology 3 (8): 835- 841.

Koonrungsesomboon, N., Na-Bangchang, K., \& Juntra Karbwang, J. 2014. Therapeutic potential and pharmacological activities of Atractylodes lancea (Thunb.) DC. Asian Pacific Journal of Tropical Medicine: 421-428.

Lalitha, K. G., Venkatachalam, T., Rathinavel, G., Kishor Kumar, V. K., \& Kalaiselvi, P. 2010. Evaluation of analgesic activity of Evodia lunu-ankenda (Gaertn) Merr. Der Pharmacia Sinica 1(1): 7-10.

Larousse; Encyclopedia of Médicinal Plants. 2001. Identification,
Preparations, Care. 2nd Edition. Dorling Kindersiey Limited, Londres. pp.335.

Larousse Médical. 2006. Dictionnaire et encyclopédie (broché). Éd 2006 , pp. 296.

Larousse Médical. 2006. Dictionnaire et encyclopédie (broché). Éd 2006, pp. 517.

Le Bars, D., Gozariu, M., \& Cadden, S. 2001. Animal models of nociception. Pharmacologial Reviews 53(4): 597-652.

Lindsey, K., Jager, A. K., Raidoo, D. M., \& Staden, J. V. 1999. Screening of plants used by South African traditional healers in the treatment of dysmenorrhoea for prastaglandinsynthesis inhibitors and uterine relaxing activity. Journal of Ethnopharmacology 64(1): 9-14

MacDonald, A. D., Woolfe, G., Bergel, F., Morrison, A. L., \& Rinderknecht, H. 1946. Analgesic action of pethidne derivatives and related compounds. British Journal of Pharmacology 1: 4-14

Makambila-Koubemba, M. C., Abena, A. A., \& Ndounga, M. 1997. Activité antalgique d'un extrait brut d'Ageratum conyzoides chez la Souris. Etude comparative au tetra. Pharmacopée et Médicine Traditionelle Africaine 9: 34-39.

Menèndez, L., Lastra, A., Hidalgo, A., \& Baamonde, A. 2002. Unilateral hot plate test: a simple and sensitive method for detecting central and peripheral hyperalgesia in mice. Journal of Neuroscience Methods 113(1): 91-7.

Mulder, G. B. \& Pritchett, K. 2004. Rodent analgesiometry: the hot plate, tail flick and von frey hairs. Animal Science 43(3): 54-5.

Ndiaye, M., Sy, G. Y., Dièye, A. M., Touré, M. T., \& Faye, B. 2006. Evaluation de l'activité anti-inflammatoire de feuilles d'annona reticulat (annonaceae) sur l'oedème aigu de la patte de rat indidt par la carragénine. Pharmacopée et Médicine Traditionelle Africaine XIV: 179-186.

Ohishia, T., Gotob, S., Monirac, P., Isemurab, M., \& Nakamurac, Y. 2016. Anti-inflammatory action of green tea. AntiInflammatory \& Anti-Allergy Agents in Medicinal Chemistry 15: 74-90.

Panda, B. B., Gaur, K., Kori, M. L., Tyagi, L. K., Nema, R. K., Sharma, C. S., \& Jain, A. K. 2009. Anti-inflammatory and analgesic activity of jatropha gossypifolia in experimental animal models. Global Journal of Pharmacology 3(1): 01-05.

Raj, P. P. 1996. Pain mechanisms. In Pain medicine: a comprehensive review. $1^{\text {st }}$ ed. Mosby Year Book, Inc., St. Louis, USA. pp. 12-24.

Ramirez, M. R., Guterres, L., Dickel, O. E., Castro, M. R., Henriques, A. T., Souza, M. M., \& Barros, D. M. 2010. Preliminary studies on the antinociceptive activity of Vaccinium ashei berry in experimental animal models. Journal of Medicinal Food 13(2): 336-342.

Riahi, R. C., Tarhouni, S., \& Kharrat, R. 2011. Criblage de l'effet anti-inflammatoire et analgesique des algues marines de la mer mediterranee. Archives de I'institute Pasteur de Tunis 88: 14.

Sanogo, R., Maiga, A., \& Diallo, D. 2006. Activites analgesique et anti-inflammatoire des extraits de maytenus senegalensis, stereospermum kuntrianum et tricrilia emetica utilisées dans le traitement traditionnel des dysménorrhées au Mali. Pharmacopée et Médicine Traditionelle Africaine XIV: 123-136.

Sellam, K., Ramchoun, M., Alem, C., Khallouki, F., El Moualii, B., \& El Rhaffari, L. 2012. Chemical composition antioxidant and antimicrobial activities of essential oil of Warionia saharae from oases of Morocco. Gas ChromatographyBiochemicals, Narcotics and Essential Oils; Bekir Salih, Ömür Celikeb çak. Eds.; InTech. pp. 213-220.

Sen, T. \& Nag, C. A. K. 1991. Antiinflammatory evaluation of Pluchea indica root extract. Journal of Ethnopharmacology 33: 135-141.

Turner, R. A. 1965. Screening Methods in Pharmacology. New 
York: Academic Press. pp. 100.

Seo, M. J., Kim, S. J., Kang, T. H., Rim, H. K., Jeong, H. J., Um, J. Y., Hong, S. H., \& Kim, H. M. 2011. The regulatory mechanism of $\beta$-eudesmol is through the suppression of caspase-1 activation in mast cell-mediated inflammatory response. Immunopharmacology and Immunotoxicology 33(1): 178-185.

Sieg-mund, E., Cadmus, R., \& Lu, G. 1957. A method for evaluating both non-narcotic and narcotic analgesics. Proceedings for the Society of Experimental Biology and Medicine 95 (4): 729-731.

Sherwood, E. R. \& Toliver-Kinsky, T. 2004. Mechanisms of the inflammatory response. Best Practice and Research Clinical Anaesthesiology 18: 385-405.

Silva, J., Abebe, W., Sousa, S. M., Duarte, V. G., Machado, M. I. L., \& Matos, F. J. A. 2003. Analgesic and anti-inflammatory effects of essential oils of Eucalyptus. Journal of Ethnopharmacology 89: 277-283.

Soro, T. Y., Néné-bi, A. S., Zahoui, O. S., Yapi, A., \& Traoré, F. 2015. Activité anti-inflammatoire de l'extrait aqueux de Ximenia americana (Linné) (Olacaceae). Journal of Animal \& Plant Sciences 24(3): 3802-3813.

The Institutional Animal Care and Use Committee (IACUC). Hot Plate Test. Guidelines and Standard Procedure: iacuc.ucsf.edu/Policies/HotPlateTest.doc (Effective Date 10.11.2019)

Tjolsen, A., Osland, A. E., Bergea, O. G., \& Hole, K. 1991. The increasing-temperature hot-plate test: An improved test of nociception in mice and rats. Journal of Pharmacological Methods 25: 241-250.

Winter, C. A., Risley, E. A, \& Nuss, G. W. 1962. Carrageenaninduced edema in hind paws of the rats as an assay of antiinflammatory drugs. Proceedings of the Society for Experimental Biology and Medicine 3: 544-547.

Yakoubi, M., Belboukhari, N., Sekkoum, K., Cheriti, A., Bouchekara, M., \& Aboul-Enein, H. Y. 2015. The chemical composition of essential oil of Warionea sabarae Benth \& Coss. (Fam. Asteraceae) from Southern Algeria. Current Bioactive Compounds 11(2): 116-121.

Zimmermann, M. 1983. Ethical guidelines for investigations of experimental pain in conscious animals. Pain 16(2): 109-110.

Znini, M., Cristofari, G., Majidi, L., Harrak, A., Paolini, J., \& Costa, J. 2013. In vitro antifungal activity and chemical composition of $W$ arionia sabarae essential oil against 3 apple phytopathogenic fungi. Food Science and Biotechnology 22(S1): 113-119. 